\title{
Inhibition of ACC-dependent Ethylene Production in Apple Fruit Discs by a Cell Wall Component from Peach Fruit
}

\author{
Takaya Moriguchi*, Tetsuro Sanada and Keiichi Tanaka \\ Fruit Tree Research. Station, Tsukuba, Ibaraki 305
}

\begin{abstract}
Summary
Substance(s) inhibitory to ACC-dependent ethylene production in the alcohol-insoluble solids (AIS) fraction from peach fruit was assessed in apple fruit discs.

The supernatant from AIS digested with pectolyase Y.23 in distilled water inhibited ethylene production in apple fruit dises. Separation of the supernatant on a PD-10 column indicated that the inhibitory substance(s) was associated with the low molecular weight fraction. The inhibitory effect of the supernatant was lost upon dialysis against distilled water. The inhibitory fraction appeared as a single entity $(R f=0.44)$ when separated by thin layer chromatography. Inhibitory substance(s) was also released by macerozyme and cellulase digestion or by autocatalytic digestion of freshly prepared peach fruit homogenate. These data indicate that peach fruit may release a substance(s) which inhibits ethylene production.
\end{abstract}

\section{Introduction}

Fruit ripening is a complicated phenomenon involving many coordinated steps. Transgenic toma. to fruit having the antisense gene of PTOM 13 (later verified as 1-aminocyclopropane-1-carboxylic acid (ACC) oxidase] revealed a delay of the ripening process accompanying the inhibition of ethylene production (Hamilton et al., 1990). Thus, ethylene has been thought as a trigger of fruit ripening. Applications of aminoethoxyvinylglycine (2-amino-4 [2-aminoethoxy]-trans-3-butenoic acid) (AVG) has been examined for the delay of ripening and enhancement of fruit quality (Bangerth, 1978). This benefit is derived from the inhibition of ethylene production by AVG via its suppression of the conversion of $S$-adenosylmethionine (SAM) to ACC (Yang and Hoffman, 1984).

Received for publication 19 January 1995.

This work was entrusted to the Fruit Tree Research Station by the Science and Technology Agency, using the Special Coordination Funds for Promoting Science and Technology.

Contribution No. A-326 of the Fruit Tree Research Station.

* Present address : Okitsu Branch, Fruit Tree Research Station, Okitsu, Shimizu, Shizuoka 424-02.
Ripening (softening) of peach fruit advances dramatically resulting in rapid deterioration of fruit quality. In the process the cell walls are rapidly broken down, most particularly into polyuronide components (Pressey et al., 1971). It has been suggested that fragments derived from plant cell walls can serve as regulatory molecules including regulation of ethylene production (Albersheim et al., 1983). It has also been suggested that cell wall fragments derived from peach fruit may have some functional role in the ripening (softening) process and regulation of ethylene production. Tong et al. (1986) reported that cell wall fragments of pear cell suspension cultures digested with macerase led to a rapid and transient production of ethylene by the cells. Similarly, pectic materials stimulated ethylene production when vacuum-infiltrated into whole mature green tomato fruit (Tong and Gross, 1990). Pectic oligomers also induce and regulate ethylene biosynthesis in cultured pear cells (Campbell and Labavitch, 1991a) and tomato pericarp discs (Campbell and Labavitch, 1991b).

In this paper, we report the inhibitory effect on ethylene production by a fraction derived from alcohol-insoluble solids (AIS) of peach fruit, and partial purification of this fraction. 


\section{Materials and Methods}

\section{Chemical}

$A V G$ and $A C C$ were obtained from Sigma Chemical Co., St. Louis, USA ; pectolyase Y-23 from Seishin Pharmaceutical Co., Ltd., Tokyo, Japan ; and glucoamylase from Seikagaku Corp., Tokyo, Japan.

\section{Preparation of AIS}

Peach ('Hakuho' and 'Hakuto') fruits for the extraction of AIS were harvested from mature trees growing at the Chiyoda Experimental Orchard of the Fruit Tree Research Station (Tsukuba). The fresh pulp tissue was cut into small pieces and homogenized in 3 volumes of $80 \%$ ethanol. After $\mathrm{pH}$ adjustment to about 7 with $0.1 \mathrm{~N} \mathrm{NaOH}$, the homogenate was heated at $80{ }^{\circ} \mathrm{C}$ for $10 \mathrm{~min}$, and then centrifuged at $10,000 \times \mathrm{g}$ for $15 \mathrm{~min}$. The pellet was washed twice with 2 volumes of $80 \%$ ethanol and the residue was dried under vacuum.

\section{Partial purification}

AIS (equivalent to $40 \mathrm{~g}$ fresh weight) was resuspended in $30 \mathrm{ml}$ of distilled water and digested with $5 \mathrm{mg}$ glucoamylase at $37{ }^{\circ} \mathrm{C}$ for $3 \mathrm{hr}$. The reaction was stopped by boiling the mixture for $15 \mathrm{~min}$. The mixture was then passed through a glass filter, and the residue was resuspended in $25 \mathrm{ml}$ distilled water and incubated with $20 \mathrm{mg}$ pectolyase $\mathrm{Y}-23$ at $37^{\circ} \mathrm{C}$ for $24 \mathrm{hr}$. The mixture was then boiled for $15 \mathrm{~min}$, and passed through a glass filter. The filtrate fraction was collected and concentrated to $2.5 \mathrm{ml}$ by vapour mix. The concentrated filtrate was passed through a PD-10 column (Pharmacia LKB Biotechnology AB, Uppsala, Sweden) as specified in the manufacturer's mannual and the low molecular weight fraction $(6 \sim 12 \mathrm{ml})$ was collected. This fraction was further concen. trated into a small volume by vapour mix and developed on thin layer chromatography (TLC) (Kieselgel $60 \mathrm{~F}_{254}$, E. Merck, Frankfurter Strasse 250 , Germany). The solvent for the 1 st develop. ment step was $n$-butyl alcohol : pyridine : distilled water $=(6: 4: 3)$. The same solvents at $1: 1: 1$ were used in the 2 nd and 3 rd development steps. In a preliminary experiment, we found that the inhibitory effect on ethylene production was in the low $R f$ values. Subsequently, fractions of average $\mathrm{Rf}=0.24(\# 1)$ and $0.44(\# 2)$ under UV light
$\left(A_{254}\right)$ were recovered from TLC plates, using the same $1: 1: 1$ solvent mentioned above. The recovered fractions were evaporated completely under vacuum and tested in the ethylene assay.

\section{Autocatalytic experiment}

Fresh peach fruits $(300 \mathrm{~g})$ were homogenized in distilled water $(600 \mathrm{ml})$ and centrifuged at $750 \times \mathrm{g}$ for $20 \mathrm{~min}$. The pellet fraction was resuspended in $40 \mathrm{ml}$ of distilled water. Ten $\mathrm{ml}$ of this mixture were added into A.IS with 3 drops of toluene (as an antiseptic) and incubated for $20 \mathrm{hr}$ at $30{ }^{\circ} \mathrm{C}$. After incubation, the mixture was boiled and passed through : a glass filter. The filtrate was tested in the ethylene assay. Boiled peach fruit homogenates were used as controls.

\section{Ethylene assay}

The ethylene assay solution consisted of $3.5 \mathrm{ml}$ of $0.1 \mathrm{M}$ Hepes-KOH buffer ( $\mathrm{pH} 5.9), 1.5 \mathrm{ml}$ of inhibitor solution or $1.5 \mathrm{ml}$ of distilled water (as control), $20 \mu \mathrm{l}$ of ACC (stock solution; $1 \mathrm{mg} \cdot \mathrm{ml}^{-1}$ ), $100 \mu \mathrm{l}$ of $\mathrm{AVG}$ (stock solution; $1 \mathrm{mg} \cdot \mathrm{ml}^{-1}$ ), mannitol for osmoregulation (final concentration 0.6 M) and about $1 \mathrm{~g}$ apple fruit discs (2 pieces of $\emptyset$ $0.85 \mathrm{~cm} \times 1 \mathrm{~cm})$ in a glass tube $(\varnothing 1.5 \mathrm{~cm} \times 10.5$ cm). Apple ('Fuji') was used for the assay because of ease of handling and availability throughout the year. After mixing well, the assay tubes were sealed tightly with a silicone cap, and left in the dark at room temperature. Ethylene production rates were determined at 2-hour intervals. A $3 \mathrm{ml}$ gas sample was withdrawn from the gas phase using a syringe fitted with a hypodermic needle, and analyzed at $80{ }^{\circ} \mathrm{C}$ in a gas chromatograph equipped with an alumina column and FID and quantified by comparison with the retention time and peak area of standard samples. Immediately after sampling the test tubes were opened to allow in fresh air and sealed again for the next incubation period. As ethylene production in the control varied due to the physiological differences of apple fruit discs employed in the assay, ethylene production was determined in at least 2 replications and results are generally presented as $\%$ of the control value.

\section{Results and Discussion}

Pectolyase Y.23 digest of AIS from unripened (over $8 \mathrm{lb} \cdot$ in $^{-2}$ firmness by penetrometer fitted 
with an $0.8 \mathrm{~cm}$ probe) and ripened (almost 0 $\mathrm{b} \cdot \mathrm{in}^{-2}$ ) peach fruit strongly inhibited ethylene production by apple fruit discs (Fig. 1). Macerozyme and cellulase digests also effectively inhibited ethylene production (data not shown). After $8 \mathrm{hr}$ incubation, macerozyme and cellulase digests inhibited ethylene production by 32 and $29 \%$, respectively relative to the control. After partial purification of the pectolyase digest on a PD-10 column, we found that the low molecular weight fraction $(6 \sim 12 \mathrm{ml})$ was the active component in inhibiting ethylene production (Table 1). Dialysis against distilled water of the supernatant from pectolyase Y.23 digestion caused complete loss of its inhibitory effect (Table 2). Accordingly, the molecular weight of the inhibitory substance(s)

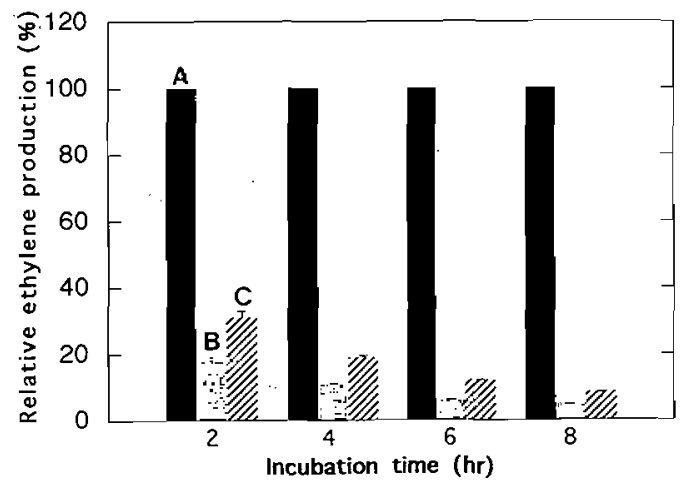

Fig. 1. Effect of the AIS extracts after pectolyase Y-23 digestion of peach fruit on ethylene production by apple discs.

A ; control. B ; unripened peach fruit. C ; ripened peach fruit. was estimated to be less than 3,000 . Recovery of the separate fractions $[R f=0.24(\# 1)$ and $R f=$ $0.44(\# 2)$ ] from TLC plates indicated that fraction in \#2 had the highest inhibitory effect (Fig. 2). Spectrophotometric scanning of fraction ( \#2) from $A_{700}$ to $A_{190}$ indicated a small absorbance peak at about $A_{250}$ suggesting the existence of phenolics (data not shown). The results from analysis for several carbohydrates in fraction \#2 are shown in Table 3. It was clear that these preparations contained sugars, uronide and phenolic compounds.

Campbell and Labavitch (1991a) reported that pectic oligomers in degree of polymerization (DP) from 5 to 13 galacturonic acid, with $90 \%$ of carbohydrates in DP 7 to 9 , promoted ethylene production in pear cells. We also examined the effects of purified pectic oligomers in DP 2 to 12 on ethylene production in our assay system and obtained variable results (data not shown). This implies that the cell wall component from peach that inhibits ethylene production is not simple structure as oligomers of galacturonic acid. Gross (1985) and Kim et al. (1987) reported that 400 and $800 \mu \mathrm{g}$ galactose $\cdot \mathrm{g}^{-1}$ fresh weight stimulated ethylene production in tomato fruit. However, in our experiments galactose at $600 \mu \mathrm{g} \cdot \mathrm{g}^{-1}$ fresh weight of apple fruit discs did not stimulate ethylene production (Table 4). This suggests that the stimulatory effect of galactose on ethylene production may depend on the commodity. Furthermore, these workers used mature green tomato, and we used already harvested and stored apple fruit, and this may also contribute to the different response to galactose. Standard compounds (galac-

Table 1. Inhibition of ethylene production by the fractions obtained via passage through PD- 10 column ${ }^{2}$.

\begin{tabular}{cccc}
\hline \hline \multirow{2}{*}{$\begin{array}{l}\text { Incubation time } \\
\text { in assay } \\
\text { solution (hr) }\end{array}$} & Control & \multicolumn{2}{c}{ Fractions } \\
\cline { 3 - 4 } & $\left(\mathrm{nl} \mathrm{C}_{2} \mathrm{H}_{4} \cdot \mathrm{gFW}^{-1} \cdot \mathrm{h}^{-1}\right)$ & High molecular & Low molecular \\
\hline & & \multicolumn{3}{c}{ Relative ethylene production against control } \\
2 & 9.1 & $87 \pm 3$ & $71 \pm 6$ \\
4 & 35.7 & $82 \pm 1$ & $46 \pm 4$ \\
6 & 46.6 & $89 \pm 1$ & $39 \pm 1$ \\
8 & 46.9 & $87 \pm 10$ & $27 \pm 1$ \\
\hline
\end{tabular}

${ }^{\tau}$ AIS digested by pectolyase Y. 23 was applied to PD. 10 column, and the resultant fractions were passed through a glass filter and added to the assay solution (see Methods). 
Table 2. Effect of dialysis of the AIS extracts after pectolyase Y. 23 digestion on ethylene production by apple discs.

\begin{tabular}{cccc}
\hline \hline $\begin{array}{l}\text { Incubation time } \\
\text { in assay } \\
\text { solution (hr) }\end{array}$ & Control & \multicolumn{2}{c}{ Treatment } \\
\cline { 3 - 4 } & $\left(\mathrm{nl} \mathrm{C}_{2} \mathrm{H}_{4} \cdot \mathrm{gFW}^{-1} \cdot \mathrm{h}^{-1}\right)$ & Dialysis & Without dialysis \\
\hline & \multicolumn{4}{c}{ Relative ethylene production against control } \\
4 & 17.9 & $107 \pm 6$ & $31 \pm 2$ \\
6 & 52.9 & $105 \pm 2$ & $18 \pm 0$ \\
8 & 61.8 & $118 \pm 19$ & $14 \pm 2$ \\
& 66.3 & $96 \pm 12$ & $8 \pm 1$ \\
\hline
\end{tabular}

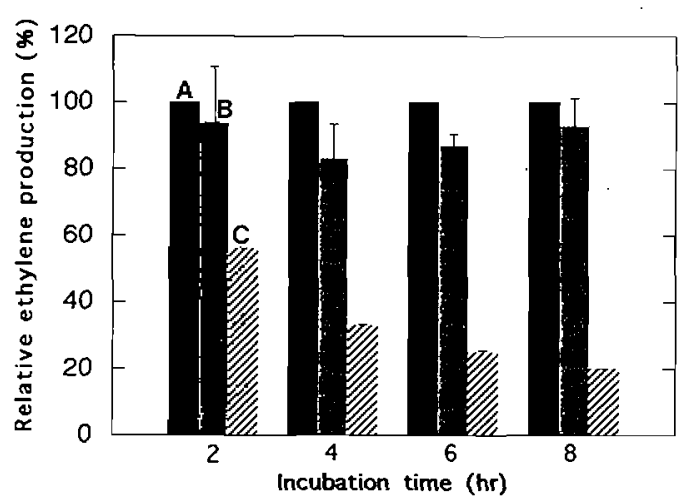

Fig. 2. Inhibition of ethylene production by the fractions recovered following TLC plate.

A ; control.

B ; \#1.

C ; \#2.

Table 3. Analysis of peach digest fraction \# $2^{2}$.

\begin{tabular}{lrl}
\hline \hline & \multicolumn{2}{c}{ Content } \\
\hline Total sugar $\left(\mathrm{mg} \cdot \mathrm{ml}^{-1}\right)$ & $7.9 \pm 0.4$ & (as glucose) \\
Uronic acid $\left(\mu \mathrm{g} \cdot \mathrm{ml}^{-1}\right)$ & $39.9 \pm 0.6$ & (as galacturonic acid) \\
Flavanol tannin $\left(\mu \mathrm{g} \cdot \mathrm{ml}^{-1}\right)$ & $94.5 \pm 26.0$ & (as catechin) \\
Phenol $\left(\mu \mathrm{g} \cdot \mathrm{ml}{ }^{-1}\right)$ & $636.5 \pm 4.9$ & (as catechin) \\
Chlorogenic acid $\left(\mu \mathrm{g} \cdot \mathrm{ml}^{-1}\right)$ & $40.0 \pm 0$ & (as chlorogenic acid) \\
\hline${ }^{2}$ The following methods & were employed : anthrone (Morris. 1948), car- \\
bazole (Dische, 1947). Vanilin. $\mathrm{H}_{2} \mathrm{SO}_{4}$ method (Sondheimer. 1953). \\
Folin-Denis (Folin and Denis, 1915), diazo method (Nakabayashi and \\
Ukai. 1963).
\end{tabular}

turonic acid ; 100,10 and $1 \mathrm{mg} /$ assay : glucose ; 300,30 and $3 \mathrm{mg} /$ assay : mannose, fucose, galactose, rhamnose, xylose and arabinose ; 0.6 $\mathrm{mg}$ /assay) were also tested in our assay system (Table 4). Except for galacturonic acid at $100 \mathrm{mg}$. we did not observe any distinct inhibitory effect on ethylene production. Galacturonic acid at 100 mg inhibited ethylene production by $72 \%$ during the $8 \mathrm{hr}$ incubation. From the data in Table 3 , the galacturonic acid component in fraction \# 2 was estimated to be about $40 \mathrm{mg} \cdot \mathrm{ml}^{-1}$. However, comparative analysis following addition of galacturonic acid to fraction \#2 on dilution (data not shown) indicated that the inhibitory effect of fraction \#2 was not due to the high concentration of galacturonic acid.

The supernatant from AIS fraction was slightly acidic with a pH in the range of 5.3 to 4.6 after 8 hr incubation. Neither malic acid nor citric acid inhibited ethylene production in our system (Table 5). It was apparent, therefore, that the ethylene in hibitory substance(s) was different other than these two and its effect was not as a consequence of acidic pH. Although TLC analysis of fraction \# 2 utilizing the $p$-toluenesulphonic acid method (Roux, 1957) and diphenylamine-aniline method (Bailey and Bourne, 1960) of detection revealed the presence of hexose and phenolic compounds, these compounds existed separately and not as the aglycon (data not shown).

We also examined whether peach fruit can release the inhibitory substance(s) without pectolyase Y-23 digestion. AIS prepared from unripened and ripened peach fruits were resuspended in distilled water, and the extract obtained after $24 \mathrm{hr}$ was directly used for assay of ethylene production. There was no inhibitory effect on ethylene production by the AIS fraction from unripened fruit. However, the fraction from ripened fruit partially inhibited ethylene production (Fig. 3). To examine for possible autocatalytic effects in the peach fruit itself, AIS was incubated with freshly 
Table 4. Effect of various carbohydrates on ethylene production by apple discs.

\begin{tabular}{|c|c|c|c|c|c|}
\hline \multirow[t]{2}{*}{ Carbohydrate } & \multirow{2}{*}{$\begin{array}{c}\text { Concentration } \\
\text { (mg/assay) }\end{array}$} & \multicolumn{4}{|c|}{ Incubation time in assay solution (hr) } \\
\hline & & 2 & 4 & 6 & 8 \\
\hline & & \multicolumn{4}{|c|}{ Relative ethylene production against control (\%) } \\
\hline $\begin{array}{l}\text { Galacturonic } \\
\text { acid }\end{array}$ & $\begin{array}{r}1 \\
10 \\
100\end{array}$ & $\begin{array}{l}129 \pm 1 \\
130 \pm 2 \\
120 \pm 1\end{array}$ & $\begin{array}{r}109 \pm 4 \\
101 \pm 1 \\
83 \pm 2\end{array}$ & $\begin{array}{r}103 \pm 19 \\
99 \pm 3 \\
72 \pm 5\end{array}$ & $\begin{array}{l}99 \pm 12 \\
78 \pm 1 \\
72 \pm 0\end{array}$ \\
\hline Sucrose & $\begin{array}{r}40 \\
400\end{array}$ & $\begin{array}{l}137 \pm 6 \\
113 \pm 3\end{array}$ & $\begin{array}{l}122 \pm 10 \\
114 \pm 9\end{array}$ & $\begin{array}{l}140 \pm 15 \\
128 \pm 0\end{array}$ & $\begin{array}{l}133 \pm 10 \\
126 \pm 3\end{array}$ \\
\hline Glucose & $\begin{array}{r}3 \\
30\end{array}$ & $\begin{array}{l}106 \pm 5 \\
115 \pm 20\end{array}$ & $\begin{array}{r}112 \pm 5 \\
98 \pm 18\end{array}$ & $\begin{array}{l}120 \pm 4 \\
109 \pm 10\end{array}$ & $\begin{array}{l}97 \pm 15 \\
94 \pm 1\end{array}$ \\
\hline Fructose & $\begin{array}{r}3 \\
30\end{array}$ & $\begin{array}{l}104 \pm 6 \\
112 \pm 10\end{array}$ & $\begin{array}{l}114 \pm 10 \\
113 \pm 13\end{array}$ & $\begin{array}{r}86 \pm 1 \\
103 \pm 9\end{array}$ & $\begin{array}{r}95 \pm 3 \\
103 \pm 4\end{array}$ \\
\hline Sorbitol & $\begin{array}{r}1 \\
10\end{array}$ & $\begin{array}{r}85 \pm 12 \\
111 \pm 12\end{array}$ & $\begin{array}{l}86 \pm 5 \\
93 \pm 11\end{array}$ & $\begin{array}{r}99 \pm 5 \\
104 \pm 6\end{array}$ & $\begin{array}{r}98 \pm 12 \\
102 \pm 2\end{array}$ \\
\hline Inositol & $\begin{array}{r}1 \\
10\end{array}$ & $\begin{array}{l}87 \pm 9 \\
80 \pm 4\end{array}$ & $\begin{array}{l}97 \pm 4 \\
91 \pm 8\end{array}$ & $\begin{array}{l}104 \pm 7 \\
101 \pm 1\end{array}$ & $\begin{array}{l}114 \pm 4 \\
118 \pm 1\end{array}$ \\
\hline Mannose & 0.6 & $87 \pm 18$ & $91 \pm 8$ & $98 \pm 15$ & $94 \pm 20$ \\
\hline Fucose & 0.6 & $102 \pm 5$ & $73 \pm 19$ & $91 \pm 3$ & $90 \pm 1$ \\
\hline Galactose & 0.6 & $102 \pm 7$ & $81 \pm 1$ & $86 \pm 4$ & $83 \pm 12$ \\
\hline Rhamnose & 0.6 & $98 \pm 17$ & $96 \pm 14$ & $92 \pm 15$ & $93 \pm 11$ \\
\hline Xylose & 0.6 & $105 \pm 3$ & $101 \pm 7$ & $108 \pm 2$ & $110 \pm 6$ \\
\hline Arabinose & 0.6 & $115 \pm 0$ & $89 \pm 9$ & $76 \pm 28$ & $88 \pm 10$ \\
\hline Maltose & 3 & $114 \pm 19$ & $117 \pm 15$ & $114 \pm 15$ & $107 \pm 19$ \\
\hline & 30 & $111 \pm 17$ & $107 \pm 7$ & $75 \pm 17$ & $104 \pm 7$ \\
\hline & 150 & $99 \pm 2$ & $99 \pm 10$ & $98 \pm 13$ & $87 \pm 9$ \\
\hline
\end{tabular}

Table 5. Effect of organic acids and $\mathrm{pH}$ on ethylene production by apple discs.

\begin{tabular}{|c|c|c|c|c|c|c|c|}
\hline \multirow[t]{2}{*}{ Organic acid } & \multirow{2}{*}{$\begin{array}{c}\text { Concentration } \\
\text { (mg/assay) }\end{array}$} & \multicolumn{4}{|c|}{ Incubation time in assay solution (hr) } & \multicolumn{2}{|c|}{$\mathrm{pH}^{\mathrm{z}}$} \\
\hline & & 2 & 4 & 6 & 8 & Initial & Final \\
\hline \multicolumn{8}{|c|}{ Relative ethylene production against control $(\%)$} \\
\hline \multirow[t]{2}{*}{ Malic acid } & 1 & $45 \pm 2$ & $127 \pm 1$ & $115 \pm 3$ & $93 \pm 11$ & 4.9 & 5.2 \\
\hline & 10 & $77 \pm 17$ & $86 \pm 13$ & $94 \pm 9$ & $88 \pm 12$ & 3.3 & 3.4 \\
\hline \multicolumn{8}{|l|}{ Citric acid } \\
\hline & 1 & $140 \pm 14$ & $126 \pm 9$ & $107 \pm 13$ & $78 \pm 9$ & 5.0 & 5.2 \\
\hline & 10 & $114 \pm 29$ & $121 \pm 4$ & $94 \pm 2$ & $68 \pm 2$ & 3.4 & 3.5 \\
\hline
\end{tabular}

${ }^{z} \mathrm{pH}$ was assessed before incubation (initial) and after incubation for $8 \mathrm{hr}$ (final). Data from average of 2 samples.

prepared peach fruit homogenate instead of pectolyase Y-23 digest. Addition of the resulting supernatant to the assay solution inhibited ethylene production by about $50 \%$ after a $20 \mathrm{hr}$ incubation. By contrast, addition of the supernatant following treatment with boiled peach fruit homogenate inhibited ethylene production only slightly (16\%) (Table 6). These data indicate that peach fruit may release the inhibitory substance(s) from AIS, although not effectively as pectolyase Y.23 digestion.
Thus, a cell wall component in peach fruit may have a physiological role on ripening and senescence of peach fruit via regulation of ethylene production. Once the structure of the substance(s) is determined, it may be possible to elucidate the key enzyme(s) that are likely to play a regulatory role.

\section{Acknowledgements}

We wish to thank Drs. K. Miyairi and T. Okuno (Hirosaki Univ.) for providing the pectinic oligo- 


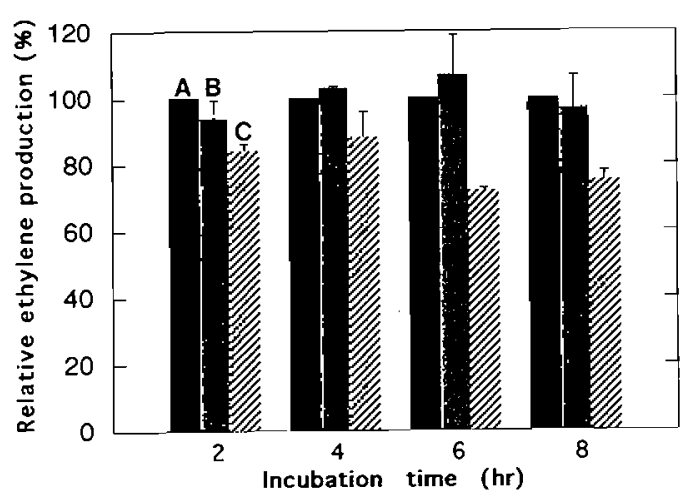

Fig. 3. Effect of the cell wall extracts from peach fruit of different ripeness on ethylene production by apple discs ${ }^{2}$.

A ; control. B ; unripened peach fruit. C ; ripened peach fruit.

" AIS from pre- and post-maturing peach fruit was resuspended in distilled water and passed through a glass filter. The resultant filtrate was added to the assay solution.

Table 6. Effect of AIS extracts digested autocatalytically by peach fruit homogenate on ethylene production by apple discs.

\begin{tabular}{|c|c|c|c|}
\hline \multirow{2}{*}{ Treatmen } & \multicolumn{3}{|c|}{ Digestion time with peach fruit homogenate (hr) } \\
\hline & 2 & 9 & 20 \\
\hline \multicolumn{4}{|c|}{ Relative ethylene production against control $(\%)^{2}$} \\
\hline No boiling & $99 \pm 15$ & $81 \pm 4$ & $50 \pm 3$ \\
\hline Boiling & $81 \pm 7$ & $77 \pm 8$ & $84 \pm 8$ \\
\hline
\end{tabular}

${ }^{z}$ Data from $8 \mathrm{hr}$ incubation in assay solution.

mers and also thank Prof. Emeritus R. J. Romani for reading the manuscript.

\section{Literature Cited}

Albersheim, P., A. G. Darvill, M. McNeil, B. S. Valent, J. K. Sharp, E. A. Nothnagel, K. R. Davis, N. Yamazaki, D. J. Gollin, W. S. York, W. F. Dudman, J. E. Darvill and A. Dell. 1983. Oligosaccharins, naturally occurring carbohydrates with biological reg. ulatory functions. p. 293-312. In : O. Ciferri and L. Dure III (eds.). Structure and function of plant genomes. Plenum Press, New York.

Bailey, R. W. and E. J. Bourne. 1960. Color reactions given by sugars and diphenylamine-aniline spray reagents on paper chromatograms. J. Chromatogr. 4:206-213.
Bangerth, F. 1978. The effect of a substituted amino acid on ethylene biosynthesis, respiration, ripening and preharvest drop of apple fruits. J. Amer. Soc. Hort. Sci. 103 : 401-404.

Campbell, A. D. and J. M. Labavitch. 1991 a. Induction and regulation of ethylene biosynthesis by pectic oligomers in cultured pear cells. Plant Physiol. 97 : 699-705.

Campbell, A. D. and J. M. Labavitch. 1991b. Induction and regulation of ethylene biosynthesis and ripening by pectic oligomers in tomato pericarp discs. Plant Physiol. 97 : 706-713.

Dische, Z. 1947. A new specific color reaction of hex uronic acids. J. Biol. Chem. $167: 189-198$.

Folin, O. and W. Denis. 1915. A colorimetric method for the determination of phenols (and phenol derivatives) in urine. J. Biol. Chem. $22: 305-308$.

Gross, K. C. 1985. Promotion of ethylene evolution and ripening of tomato fruit by galactose. Plant Physiol. 79: 306-307.

Hamilton, A. J., G. W. Lycett and D. Grierson. 1990. Antisense gene that inhibits synthesis of the hormone ethylene in transgenic plants. Nature 346: 284-287.

Kim, J., K. C. Gross and T. Solomos. 1987. Characterization of the stimulation of ethylene production by galactose in tomato (Lycopersicon esculentum Mill.) fruit. Plant Physiol. 85 : 804-807.

Morris, D. L. 1948. Quantitative determination of carbohydrates with dreywood's anthrone reagent. Science $107: 254-255$.

Nakabayashi, T. and N. Ukai. 1963. Browning of peach fruit by polyphenol oxidase. J. Japan. Soc. Food Tech. 10:211-216.

Pressey, R., D. M. Hinton and J. K. Avants. 1971. Development of polygalacturonase activity and solubilization of pectin in peaches during ripening. J. Food Sci. 36: 1070-1073.

Roux, D. G. 1957. Some recent advances in the identification of leuco-anthocyanins and the chemistry of condensed tannins. Nature 180:973-975.

Sondheimer, E. 1953. On the relation between spectral changes and $\mathrm{pH}$ of the anthocyanin pelargonidin 3-mono-glucoside. J. Amer. Chem. Soc. 75 : $1507-1508$

Tong, C. B., J. M. Labavitch and S. F. Yang. 1986. The induction of ethylene production from pear cell culture by cell wall fragments. Plant Physiol. 81 : 929-930.

Tong, C. B. S. and K. C. Gross. 1990. Stimulation of ethylene production by cell wall component from mature green tomato fruit. Physiol. Plant. 80 : 500-506.

Yang, S. F. and N. E. Hoffman. 1984. Ethylene biosynthesis and its regulation in higher plants. Ann. Rev. Plant Physiol. 35 : 155-189. 
リンゴ果実切片の ACC 依存エチレン発生を抑制するモモ細胞壁画分について

森口卓哉* ·真田哲朗・田中敬一

果樹試験場 305 茨城県つくば市藤本 2-1

\begin{abstract}
摘
モモ果実細胞壁画分に，リンゴ果実切片のACC 依 存エチレン発生を抑制する物質を見いだしたので，そ の諸性質を検討するとともに部分精製を試みた。

1. 軟化前後のモモ果実を $80 \%$ エタノール抽出し, アルコール不溶性固形物（AIS）画分を得た. AISを ペクトリアーゼY-23とともに蒸留水に再照濁し, 酵 素消化後，その上清をエチレン測定に供試したところ， 著しいエチレン発生抑制効果が認められた。

2. ペクトリアーゼ Y-23 処理後の上清を PD-10力 ラムに通すと, エチレン発生抑制効果は低分子画分 (6〜12 ml) において見いだされた。 さらに，ペクト リアーゼ Y-23 処理後の上清を透析すると抑制効果が 消失した。このためこの物質の分子量は少なくとも 3,000 以下であることが推定された。

3. エチレン発生抑制効果の認められた低分子画分 を薄層クロマトグラフィー（TLC）で展開すると，低 いRf 値に扔いてエチレン発生抑制効果が認められた。 続いて\#1（Rf=0.24）および\#2（Rf=0.44）の2つ の画分について TLCプレートからの回収を行った。
\end{abstract} これら2つの画分では，エチレン発生抑制効果は\#2

\footnotetext{
*現在：果樹試験場與津支場 $424-02$ 静阔県清水市舆 津中町
}

において認められたこの\#2 画分には糖, ウロン酸 そしてフェノール様物質が含まれていたが，配糖体と しては存在していないことが明らかとなった。

4. エチレン発生抑制効果がモモ果実の AISにおい て認められたことより，生体でのこの物質の㗢きにつ いて調べた，軟化前後モモ果実の AIS を水抽出し, その上清をエチレン測定に供試した．軟化前の果実の AIS からの水抽出画分にはエチレン発生抑制効果が認 められなかったが, 軟化後果実の AIS からの水抽出 画分にはエチレン発生抑制効果が諰められた。さらに， モモ果実の磨砕物（モモ果肉水抽出後の残渣画分）で AISを消化後の上清をエチレン測定に供試したところ， エチレンの発生は対照区の約 50\%となった。モモ果 肉を煮沸した後，同㥞に処理したところ，エチレンの 発生抑制効果が認められなかった。

これらより，モモ果実の AISに低分子のエチレン 発生抑制物質が存在していること，またモモ果実自体 にその物質を作りだす能力のあることが明らかとなっ た.この物質はAIS (果実細胞壁) 由来と考えられる ため，モモ果実の成熟・老化過程においてこの物質が 何らかの調節機能を果たしている可能性が示唆された。 